\title{
Let the Earth Shake: From Crisis-Born Hero to Master of Civilizational Crisis
}

\begin{abstract}
A short while ago, the atrocious news of the earthquake of Messina had reached Naples and the people stood bewildered in light of a tragedy, which seemed to be of cosmic proportions. As people were learning hour by hour more terrifying particulars, their imagination fabricated even greater terror. The night before I was born, a convoy for collecting clothing for the sufferers from the earthquake from Calabria and Sicily was passing through Via Fonseca. My mother used to tell me that, upon the signals by the men of the convoy, which emerged as high-pitched shouts and invocations, the windows of the high apartment buildings would open up, the balconies would fill up with people, and the women would throw down offerings: Bed sheets, gowns, shirts, underwear, socks, shoes, infant straps, skirts, blouses for women and suits for men. In this downpour of paraphernalia, the shouting of those who were giving and those who were receiving, the crying of the women, and the clamor of the low gateways out of which ever more donors surfaced, the street was transformed into an immense oblative phantasmagoria. It was difficult to distinguish pain from celebration, pity from gratitude, receiving from giving. My mother, excited and moved, was also on the balcony to make her offering. Then, so she used to say, upon seeing a Sicilian refugee in mourning sitting on top of a wagon of this convoy with a baby on her breast, she at once felt her legs buckle. Asking for support from her neighbors, she was carried home. They sat her down in the nearest chair. [...] When she regained consciousness, she looked around with her eyes veiled in tears and murmured: "We are ready." The labor had started. ${ }^{1}$
\end{abstract}

1 Ernesto De Martino, Vita di Gennaro Esposito, Napoletano, ed. Luigi Chiriatti (Calimera: Edizioni Kurumuny, 2004), 10-11. All translations from works cited in Italian, Spanish, French, and German are mine unless otherwise indicated. 
In this passage, which forms part of a larger collection of autobiographical reflections, all of which are translated for the first time in this study, Ernesto de Martino (1908-1965) retells the story of what happened the night he was born. What is striking about this account is not only the author's evocative literary style, in which the use of a term like "oblative phantasmagoria" gives the reader an important hint at his identity as an intellectual trained in the study of religion, but also that he intentionally located his birth within the context of a cosmic drama. Entitled Via Fonseca, this passage depicts the dramatic scenes taking place in the street in front of de Martino's house after the earthquake of Messina on December 28th, 1908 as the city of Naples was flooded with displaced victims in search of food, clothing, and shelter. The 1908-earthquake shook much of Southern Italy in the early morning hours with a moment magnitude of 7.1. Lasting for a mere thirty seconds, it was a massive event of international dimensions. Leveling entire cities, permanently altering coast lines, and causing the death of close to 100,000 people, it was the most destructive earthquake ever to strike Europe in recorded history and left a lasting mark on the collective psyche of Italians for decades to come. ${ }^{2}$

What makes de Martino's retelling of his birth even more remarkable, is the fact that it is mythopoeic in nature, consisting of a combination of historical realities and the creative re-envisionings by its author. Indeed, while the devastating earthquake of Messina shook the Island of Sicily on December 28th, 1908, Ernesto was born in Naples on December 1st. In the same year, but almost a full month earlier. The earthquake narrative sets the tone for the rest of de Martino's life as the trope of the shaking earth is a repeatedly invoked in his writings. Throughout his career, the Italian thinker linked natural calamities, particularly earthquakes, with socio-political crises and intellectual debates in Italy, Europe, and the Western world as a whole. The idea of the earthquake being an "extraordinary event," which can stimulate an intellectual movement towards "deeper spiritual reflection," stems from Ernst Cassirer, the early twentieth-century neo-Kantian philosopher, whom de Martino greatly appreciated. ${ }^{3}$ Just as the Lisbon earthquake of 1755 changed the thinking of Goethe, Rousseau, Voltaire, and Kant, de Martino portrays himself as the spawn of crisis to set the theme for the century-long intellectual, spiritual, and

2 Giorgio Boatti, La terra trema: Messina 28 dicembre 1908. I trenta secondi che cambiarono l'Italia, non gli italiani (Milano: Mondadori, 2004).

3 Ernst Cassirer and James Haden, Kant's life and thought (1918; repr., New Haven: Yale University Press, 1981), 59. For a discussion of de Martino's relationship to Cassirer, see chapter 6 of part II. 
cultural aftershocks that would follow the tremblor of his birth in the early twentieth century.

Today, in light of a series of challenges - such as the corona virus pandemic, climate change, or the refugee emergencies in Europe and North Americadebates surrounding the crisis of Western civilization seem as present as never before. However, what common discourse frequently forgets is that none of these ideas are as new as they might seem. On the contrary, the history of the Western world is characterized by a long-standing tradition of crisis-thinking that exerted a deep fascination on de Martino. As scholars since his untimely death in 1965 have argued, de Martino's work was dominated by the idea of the "coexistence of modernity with that of the apocalypse." Roughly one hundred years after the publication of Oswald Spengler's Decline of the West (1918) and the ravaging of the "Spanish flu" (1918-19), this first comprehensive study of the life and work of Ernesto de Martino (1908-1965) in English language retells the dramatic story of civilizational crisis in the twentieth through the eyes of scholarship on religion.

While Ernesto de Martino is one of the greatest thinkers on religion that Italy has ever produced, his work has remained largely unknown outside of his native land until today. The reasons for this neglect, particularly in the Anglophone world, are multiple. Not only have Italian thinkers generally received less attention than their French and German counterparts, but de Martino was also a particularly complex individual with a wide range of concerns and orientations. I remember that when I first envisioned writing a book about de Martino in 2010, I climbed through the stacks of the old Alderman library at the University of Virginia, having to collect his individual works from various sections, many of them located on different floors: History of religions, cultural anthropology, folklore, musicology, transcultural psychiatry, or moral philosophy. While his thinking can be theoretically unified in its life-long fascination with the study of religion and its relationship to apocalypse and rebirth, his explorations were broad: From Ancient Greek ritual to Marxist ideology, from the Fascist sacralization of the state to Southern Italy's folkloric practices surrounding spider-bitten women, or from apocalyptic tendencies in modern French literature to the Christian roots of secularism, de Martino had something to say about all of these issues. Finally, another factor contributing to his relative neglect by international scholarship is that his thinking about crisis always involved a political dimension. Here too, his persona was anything but one-dimensional: After registering with the fascist party during his years as a

4 Placido Cherchi, "La Presenza Della Crisi, in «L'Indice» 20, 2 (1989)," L'Indice 20, no. 2 (n.d.): 36 . 
student, he later joined the anti-fascist militia, before becoming a leading force in Italian socialist and communist circles.

In light of this remarkable breadth, it is little surprising that his work has provoked a flood of studies from many different orientations. Particularly in Italy, de Martino has become a cult-like figure with followers from all possible fields of research in recent years. During my years of research in Rome, where I benefited from access to de Martino's archives hosting a treasure-trove of unpublished materials, I found knowledgeable admirers of his thinking not only in the form of historians of religion and anthropologists, but also in socialist politicians, undergraduate students of musicology, experts of Italian philosophy, and pretty much anyone stemming from the mezzogiorno, the Southern region of Italy. Although de Martino is still one of the most underestimated scholars of religion of the twentieth century, the few international studies dedicated to his work have emphasized how his true importance can be fruitfully compared to the likes of Mircea Eliade (1907-1986), Claude Lévi-Strauss (1908-2009), and Clifford Geertz (1926-2006). ${ }^{5}$ What has never been comprehensively addressed, however, is that this uniquely colorful Italian thinker positioned himself in the heart of the international discipline of religious studies. Indeed, de Martino entertained a fertile exchange with the phenomenologist of religion Mircea Eliade with whom he shared an interest in religious experience and its relevance for the political circumstances during the 193os. He engaged in a close reading of all the major works of the anthropologist Claude Lévi-Strauss, with whom he agreed that a distancing perspective that moves beyond this experience was necessary for understanding religion. Finally, he also articulated important anticipatory remarks on what would become Clifford Geertz's interpretative anthropology, sharing its emphasis on a self-reflexive encounter with foreign religious cultures.

In all of these appointments with his time's leading scholars of religion, de Martino highlighted how the twentieth-century study of religion was shaped by an underlying fascination with civilizational crisis. The Italian thinker believed that scholars of religion, just like a thermometer for body temperature, were

5 George R. Saunders, "Critical Ethnocentrism' and the Ethnology of Ernesto De Martino," American Anthropologist 95, no. 4 (1993): 875; Giordana Charuty, Ernesto de Martino: les vies antérieures d'un anthropologue (Marseille: Parenthèses, 2009), 8; Vincent Crapanzano, "Foreword," in The Land of Remorse: A Study of Southern Italian Tarantism, by Ernesto De Martino, trans. Dorothy Louise Zinn (London: Free Association Books, 2005), vii; Emilio Giacomo Berrocal, "The Post-Colonialism of Ernesto De Martino: The Principle of Critical Ethnocentrism as a Failed Attempt to Reconstruct Ethnographic Authority," History and Anthropology 20, no. 2 (2009): 123; Fabrizio M. Ferrari, Ernesto De Martino on Religion: The Crisis and the Presence (Sheffield: Equinox Publishing, 2012), xii. 
particularly sensitive to the feverishly mercurial nature of their world. For example, he argued that the scholarly projects of leading figures of the first half of the century, like Rudolf Otto and Mircea Eliade, were largely driven by the idea of civilizational crisis as a radical rupture from a premodern theological worldview. More generally, commenting on the lack of unified vision in light of the divergent perspectives, de Martino characterized the discipline itself as a field ruptured by crisis. He not only diagnosed that the leading thinkers of the study of religion in the twentieth century incarnated the socio-political tensions surrounding them, but he also believed that this led to the materialization of distinct currents of thought within the discipline. Specifically, in the twentieth century, the crisis-ridden discipline of religious studies was operating on three tectonic plates: The insider-phenomenological approach of Mircea Eliade, the outsider-explanatory approach of Claude Lévi-Strauss, and the cultural-discursive approach of Clifford Geertz.

Beyond situating him within the global discipline of religious studies through the relationship with Eliade, Lévi-Strauss, and Geertz, this study also offers an interpretation of the comprehensive corpus of his published and unpublished writings, introduces his major teachers amongst the Italian intelligentsia, and lays open the complex socio-political context that gave rise to de Martino's thinking. Born in Naples in 1908 and passing away in Rome in 1965, he lived through some of the most turbulent years of recent history: Coming of age after wwi and the time Mussolini took power to create a "third Italy," emerging as a scholar during the Civil War and the Resistance in the final years of WwII, gaining the status of a leading intellectual during the reemergence of the "Southern Question" in the 195os, before dedicating the end of his life to the investigation of apocalyptic movements in all realms of cultural production during the cold war years, de Martino was always on the forefront of intellectual and political debates that marked the Western world.

Despite his fascination with crisis as a rupture that encompassed civilization, politics, and science, de Martino's fundamental attitude remained steadfastly committed to optimism. His thought reached its most radical expression in the moments when he argued that crisis must be regarded as an opportunity for civilizational renewal or rebirth. The greatest power of de Martino's work might lie in his insistence that intellectuals can only overcome crisis if they are willing to generate a "unity of thought" that overcomes our culture's tendency to think in "separate entities" ("compartimenti-stagni"). ${ }^{6}$ This is even more true for our globalized, digitalized, and rapidly changing world. As the coronavirus

6 Ernesto De Martino, Naturalismo e storicismo nell'etnologia, ed. Stefano De Matteis (1941; repr., Lecce: Argo, 1997), 56. 
pandemic has painfully reminded us, we are increasingly confronted with complex crises that are just as biological as they are cultural, just as scientific as they are social, just as virological as they are political. In this light, de Martino's eclectic research interests, his continuous composition of speculative theories in light of empirical phenomena, and his fearless integration of contrasting disciplinary perspectives are more relevant than ever.

In this book, I decode de Martino's philosophy of civilizational crisis and cultural palingenesis by means of seven concepts that marked his scholarship over the course of his career. In the first chapter, I tell the story of the young Ernesto's early years as a student and explain how his scholarly interests in religion, like that of many of his contemporaries, can only be understood in light of "the decline of the West" (la decadenza dell'occidente), a concept that stands for the larger crisis of the modern world-view of progress and the rise of cultural pessimism during the interwar years. In chapter 2, I discuss "civil religion" (religione civile) by juxtaposing it to Eliade's "politics of nostalgia," arguing that the Italian scholar's thinking was based on a palingenetic conception of time according to which political religion is both the return to something from the past and the invention of something new. In chapter 3 , I elaborate on "the crisis of the presence" (la crisi della presenza), arguing that de Martino used it not only to explain the origin of magic in non-modern societies, but also to warn of a contemporary crisis, namely the rise of magical thinking during the Second World War. In discussing the theory of "de-historification" (destorificazione) in chapter 4, I argue that it allowed the Italian thinker to integrate the positions of the insider-phenomenological approach of Eliade and the outsiderexplanatory approach of Lévi-Strauss as religion is both a flight from history and an effective means to transform it. In chapter 5 , I introduce the concept of "critical ethnocentrism" (etnocentrismo critico), which de Martino developed during his ethnographic explorations of the Italian South in the 1950s, arguing that it is marked by a series of traits that can also be found in Lévi-Strauss's Tristes Tropiques and post-colonial anthropology. Centered on the "loyalty to the cultural homeland" (fedeltà alla patria culturale), chapter 6 shows that de Martino, despite having much in common with interpretative and self-reflexive anthropology of the likes of Clifford Geertz, virulently opposed any form of cultural relativism, remaining firmly committed to the values of Western civilization. Finally, chapter 7 explores de Martino's final notes redacted before his death in order to explore the "ethos of transcendence" (ethos del trascendimento), a principle that forms the foundation for a strong cognitive and moral model of truth, which promises to offer an effective alternative to post-modern thinking. 
Thus, if much of recent scholarship on de Martino has started to celebrate him as an early harbinger of the various turns that characterize postcolonialism, poststructuralism, and postmodernism, this study makes a different argument. ${ }^{7}$ De Martino's work was profoundly dialectical in nature. If it is post-modern, then only inasmuch as it remained deeply grounded in modernity. As a consequence, his work should be regarded as an anticipated analysis of and resolute response to the cultural-discursive paradigm that came to dominate the humanities in recent decades. Although many of his political and intellectual choices will sound questionable and smack of a naïve form of modernism - particularly his youthful infatuation with fascism and his steadfast commitment to ethnocentrism-his value lies precisely in his commitment to a dialectical type of science. De Martino's dialectical thinking encourages us to Let the Earth Shake because any crisis offers science an opportunity to improve its methods and to increase our knowledge about the world. Unlike contemporary scholars of religion, who have rightly been accused of believing their science to be "incapable of learning from its mistakes or correcting its weaknesses," ${ }^{8}$ de Martino was confident that science is capable of growth and progress.

7 Fabrizio M. Ferrari, Ernesto De Martino on Religion.

8 Wouter J. Hanegraaff, "Reconstructing 'Religion' from the Bottom Up," Numen 63, no. 5-6 (October 14, 2016): 59 o. 